\title{
Monsanto may lose GM soya royalties throughout Brazil
}

Farmers notch up another victory in legal fight.

Luisa Massarani

15 June 2012

\section{RIO DE JANEIRO}

The biotechnology giant Monsanto is one step closer to losing billions of dollars in revenues from its genetically-modified (GM) Roundup Ready soya beans, following a ruling this week by the Brazilian Supreme Court of Justice.

The decision marks the latest chapter of an epic legal battle, in which millions of Brazilian farmers are trying to recover payments made to the company over the past decade. It could also have important implications for research in the country, some scientists say.

Brazil is the second-largest producer of genetically-modified (GM) crops, after the United States. Last year, it farmed 30.3 million hectares of the crops, mostly soya beans, but also corn and cotton. It legalized the growing of GM crops in 2005, after it

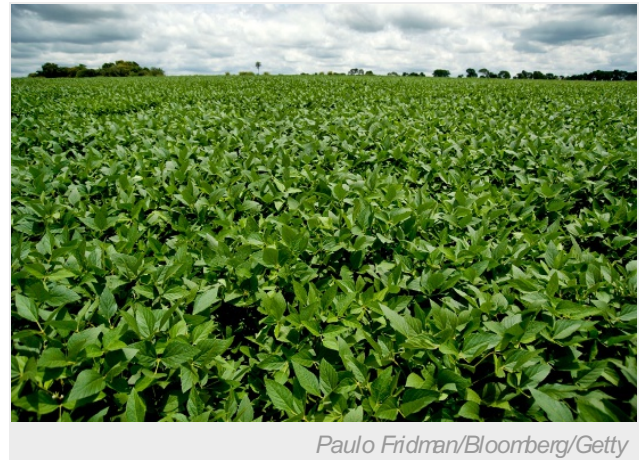

Brazilian farmers grow millions of hectares of genetically-modified soya. became clear that about three-quarters of the soya crops produced in the southern state of Rio Grande do Sul were already being grown from Roundup Ready seeds that had been smuggled in from Argentina. Because the crop is resistant to the herbicide glyphosate, marketed as Roundup, farmers can spray they fields with the chemical to control weeds without risking damage to their crops.

Since the legalization, Monsanto has charged Brazilian farmers $2 \%$ of their sales of Roundup Ready soya beans, which now account for an estimated $85 \%$ of the nation's soya-bean crop. The company also tests Brazilian soya beans that are sold as non-GM — if they turn out to be Roundup Ready, the company charges the farmers responsible for the crops some $3 \%$ of their sales.

\section{Battles begin}

In 2009, a consortium of farming syndicates from Rio Grande do Sul mounted a legal challenge to the levy, arguing that it is effectively an unjust tax on their businesses, and that it has proved impossible to keep Roundup Ready soya beans separate from conventional varieties. "The issue is that segregating GM and conventional soya is difficult, since the GM soya is highly contaminating," says João Batista da Silveira, president of the Rural Syndicate of Passo Fundo, one of the leaders of the legal action.

Monsanto argues that most Brazilian farmers still use smuggled seeds, and that the company is consequently being deprived of revenue and must recoup its costs through the levy. But the Brazilian Association of Seeds and Seedlings, a trade body, says that $70 \%$ of soya-bean farmers now buy their Roundup Ready seeds legally.

In April, Giovanni Conti, a judge in Rio Grande do Sul, decided that Monsanto's levy was illegal, noting that the patents relating to Roundup Ready soya beans have already expired in Brazil. He ordered Monsanto to stop collecting royalties, and return those collected since 2004 — or pay back a minimum of US $\$ 2$ billion. Monsanto appealed, and Conti's decision has been suspended for now, pending consideration by the Justice Tribune of Rio Grande do Sul.

But in 2011, Monsanto had also made a parallel legal bid to the Brazilian Supreme Court of Justice, the country's highest federal court. The company argued that the syndicates had no legal status to bring their case, and also that any final ruling should be limited to Rio Grande do Sul, fearing that its losses would be even greater if it applied to the whole country.

On 12 June, the judges of the Brazilian Supreme Court of Justice ruled against Monsanto, deciding unanimously that the ruling by the Justice Tribune of Rio Grande do Sul, once it is made, should apply nationwide. Monsanto has declined to comment on the case.

Some scientists fear that if the company is forced to repay royalties, it could trigger cuts in funding for biotech research. For example, 
the Brazilian Agricultural Research Corporation (Embrapa), which is affiliated with the Ministry of Agriculture, has a research partnership with Monsanto. "Although Embrapa has other financial sources, if the collection of royalties is interrupted then $\$ 5$ million to $\$ 10$ million dollars will be cut from our budget, which would stop some research projects," says Elibio Rech, an Embrapa researcher. Rech points out that royalties for intellectual property are crucial to enabling new technologies that can help sustainable development.

Carlos Fávaro, president of the Mato Grosso association of soya-bean and corn producers, agrees that intellectual property is important, and that ceasing royalty payments could impact research. But he insists that the current system is untenable: "The way of collecting royalties is unfair, [Monsanto] charges us in double: when we buy the seeds and then when we sell the soy."

Nature | doi:10.1038/nature.2012.10837 